\title{
EL OTRO*
}

Rubem Fonseca**

\section{Llegaba todos los días a la oficina a}

las ocho treinta de la mañana. El coche se detenía frente a la puerta del edificio y yo saltaba, caminaba diez o quince pasos, y llegaba.

Como cualquier ejecutivo, me pasaba las mañanas haciendo llamadas, leyendo memorandos, dictándole cartas a mi secretaria y exasperándome con los problemas. Cuando llegaba la hora de la comida, ya había trabajado bastante. Pero tenía siempre la impresión de que no había hecho nada útil.

Me tomaba una hora para comer, a veces hora y media, en uno de los restaurantes de las proximidades, y regresaba a la oficina. Había días en los que hablaba por teléfono más de cincuenta veces. Las cartas eran tantas que mi secretaria, o uno de los asistentes, las firmaban por mí. Y, siempre, al final de la jornada, tenía la impresión de que no había terminado de hacer todo lo que había que hacer. Corría contrarreloj. Me irritaba que un día feriado cayera a media semana, porque entonces tenía menos tiempo. A diario me llevaba trabajo a casa; ahí podía trabajar mejor, sin que el teléfono sonara tanto.

* Traducción de Adrián Chávez.

**Rubem Fonseca (Minas Gerais, 1925) fue un reconocido escritor y guionista de cine brasileño, ganador de reconocimientos como el Premio Camões y el Premio Juan Rulfo. Falleció en abril de 2020 . 
Un día empecé a sentir una fuerte taquicardia. Además, ese mismo día, al llegar por la mañana a la oficina apareció a mi lado, en la banqueta, un sujeto que me acompañó hasta la puerta diciendo:

-Doctor, doctor, ¿no me podría ayudar?

Le di unas monedas y entré. Poco después, cuando estaba hablando por teléfono a São Paulo, mi corazón se disparó. Por unos minutos latió a un ritmo fortísimo y me dejó extenuado. Me tuve que recostar en el sofá hasta que pasó. Estaba mareado, sudando mucho, casi me desmayo.

Esa misma tarde fui al cardiólogo. Me hizo una auscultación minuciosa, incluido un electrocardiograma de esfuerzo, y luego me dijo que lo que yo necesitaba era bajar de peso y cambiar mi estilo de vida. Me causó gracia. Entonces me recomendó dejar de trabajar un tiempo, pero le dije que eso también era imposible. Al final, me prescribió una dieta y me mandó caminar al menos dos veces al día.

Al día siguiente, a la hora de la comida, cuando fui a hacer la caminata que me recetó el médico, el mismo sujeto de la víspera me detuvo para pedirme dinero. Era un hombre blanco, fuerte, de pelo largo y castaño. Le di algo de dinero y seguí mi camino.

El médico había dicho con franqueza que, si no tenía cuidado, podría sufrir un infarto en cualquier momento. Me tomé dos tranquilizantes ese día, pero no fue suficiente para librarme totalmente de la tensión. Esa noche no me llevé trabajo a casa. Pero el tiempo no pasaba. Intenté leer un libro, solo que mi atención estaba en otra parte, en la oficina. Me puse a ver televisión, y no logré aguantar más de diez minutos. Regresé de mi caminata, después de cenar, y permanecí sentado en un sillón, leyendo los periódicos del día, irritado.

A la hora de la comida, el mismo sujeto me alcanzó para pedirme dinero.

— ¿Va a ser todos los días, o qué? —le pregunté.

—Doctor — me respondió- . Mi madre se está muriendo, necesita el medicamento y yo no conozco a nadie bueno en este mundo más que a usted.

Le di cien cruceiros. ${ }^{1}$

${ }^{1}$ El cruzeiro fue la moneda de curso legal en Brasil de 1942 a 1986 y de 1990 a 1993, cuando fue sustituido por el cruzeiro real y, más tarde, por el actual real brasileño. Cien cruceiros equivalen a 160 viejos pesos mexicanos, vigentes entonces, o a 16 centavos en nuevos pesos mexicanos. 
El sujeto se esfumó por un tiempo. Un día, a la hora de la comida, estaba a media caminata cuando apareció a mi lado.

-Doctor, mi madre se me murió.

Sin detenerme, apretando el paso, le respondí:

- Lo siento mucho.

Él alargó sus zancadas para mantenerse a mi lado, y dijo:

- Se me murió.

Traté de desembarazarme de él y comencé a caminar más rápido, casi a correr. Pero él corrió detrás de mí, repitiendo "se me murió, se me murió, se me murió", alzando ambos brazos contraídos como preparado para hacer un esfuerzo, como si sobre sus manos fueran a colocar el ataúd de la madre. Al fin me detuve, sin aliento, y le pregunté:

—¿Cuánto?

Con cinco mil cruceiros enterraba a su madre. No sé por qué lo hice, pero saqué la chequera del bolsillo y ahí, de pie a media calle, le hice un cheque por esa cantidad. Me temblaban las manos.

— ¡Y ya, por favor! -le dije.

Al día siguiente no salí a dar mi vuelta. Comí en la oficina. Fue un día terrible, todo estaba saliendo mal: se extraviaron papeles del archivo; perdimos una litigación por una diferencia mínima; un error en el plan financiero exigió nuevos y complicados cálculos presupuestarios en calidad de urgentes. Esa noche no pude dormir, ni siquiera con los tranquilizantes.

En la mañana fui a la oficina y, de cierta forma, las cosas mejoraron un poco. A medio día fui a dar la vuelta.

Vi que el sujeto que me pedía dinero estaba ahí parado, medio escondido en la esquina, espiándome, esperando a que pasara junto a él. Me giré y caminé hacia el otro lado. Poco después oí el ruido de unos zapatos golpeando el pavimento, como si alguien corriera tras de mí. Apreté el paso, con un hueco en el corazón. Era como si me estuvieran persiguiendo, un sentimiento de miedo infantil contra el que intenté luchar, pero en ese instante él ya estaba a lado mío, diciendo "doctor, doctor".

— ¿Ahora qué? -le pregunté, sin detenerme. 
Y él, manteniéndose a mi lado, dijo:

-Doctor, tiene que ayudarme, no tengo a nadie más en el mundo.

- Consígase un empleo — le respondí con toda la autoridad que pude ponerle a mi voz.

Y él dijo:

-No sé hacer nada, tiene que ayudarme.

Íbamos corriendo por la calle. Me dio la impresión de que la gente nos miraba desconcertada.

-No, no tengo que ayudarlo - le contesté.

- Sí, sí tiene que. No sabe lo que puede pasar si no lo hace.

Y entonces me tomó del brazo y me miró, y por primera vez vi bien cómo era su cara, cínica y vengativa. Me latía el corazón de nervios y de cansancio.

—Es la última vez — le dije, deteniéndome para darle dinero, no sé cuánto habrá sido.

Pero no fue la última vez. Todos los días aparecía de repente, suplicante y amenazador, caminando a mi lado, arruinando mi salud, diciendo “es la última vez, doctor”, pero nunca lo era. Me subió aún más la presión, sentía que me iba a explotar el corazón solo de pensar en él. No quería ver más a aquel hombre, ¿qué culpa tenía yo de su pobreza?

Decidí dejar de trabajar por un tiempo. Hablé con mis colegas de la junta de dirección, y acordamos una ausencia de dos meses.

La primera semana fue difícil. No es nada simple dejar de trabajar de pronto. Me sentí perdido, sin saber qué hacer. Pero poco a poco me fui acostumbrando. Me regresó el apetito. Empecé a dormir más y a fumar menos. Veía la televisión, leía, tomaba una siesta después de comer y caminaba el doble de antes, lo que me hacía sentirme mejor que nunca. Me estaba convirtiendo en un hombre tranquilo y comencé a pensar seriamente en cambiar mi estilo de vida, en dejar de trabajar tanto.

Un día salí para mi paseo habitual cuando él, el mendigo, salió de la nada. ¿Cómo había descubierto mi dirección, maldita sea?

— ¡Doctor, no me abandone! — Su voz estaba llena de dolor y resentimiento- - Usted es la única persona que tengo en el mundo, no me haga esto otra vez, necesito algo de dinero, ¡ahora sí le juro que es la última vez! 
Y acercó bien su cuerpo al mío, conforme caminábamos, y yo podía sentir su hálito amargo y podrido de famélico. Era más alto que yo, fuerte y amenazador.

Caminé en dirección a la casa, con él acompañándome, el rostro ladeado, fijo en el mío, vigilándome curioso, desconfiado, implacable, hasta que llegamos.

-Espéreme aquí - dije.

Cerré la puerta, fui a mi cuarto. Regresé, abrí la puerta y él, apenas me vio, me dijo:

- No me haga esto, doctor, no tengo a nadie más que a usted en el mundo.

No terminó de hablar, o si terminó no lo oí por el ruido del tiro. Cayó al suelo, y entonces me di cuenta de que era un niño enclenque, con acné y de una palidez tan grande que ni siquiera la sangre, que le iba cubriendo la cara, lograba esconder. 
Se prohíbe su reproducción total o parcial por cualquier medio, incluido electrónico, sin permiso previo y por escrito de los editores. 